\title{
Why is bank credit in Brazil the most expensive in the world?
}

\section{Rodrigo Zeidan ${ }^{\dagger}$}

\begin{abstract}
The article reviews the scientific literature about the determinants of credit spreads in Brazil. Econometric evidence shows that market concentration, a proxy for (un)competitive behavior, is statistically significant for all studies surveyed. We posit that that higher concentration is part of a well-defined strategy by the Central Bank of Brazil that favors prudence over efficiency. Other variables that help explain why spread in Brazil is among the highest in the world include market microstructure, operating costs, credit risk, opportunity costs, managerial quality, nominal interest rates (SELIC), market concentration, interest rate volatility, earmarked credit, and GDP.
\end{abstract}

Keywords: Bank spread, Lending rates, Borrowing costs, Market concentration. JEL Code: G21, G28, G15.

\section{Introduction}

Lending rates for consumers and businesses in Brazil have been the highest in the world for the last 25 years. Despite many changes in the Brazilian economy in the last quarter of century, one thing has remained the same: sky-high spread between deposit and lending rates. The present study is a review of previously-published scientific research on the determinants of credit spread in the Brazilian context. The goal of the paper is to explain why Brazil is such an outlier regarding borrowing costs. It should be noted that credit markets are segmented, with many types of interest rates. Here, we concentrate on typical lending rates to small and medium-sized enterprises.

Figure 1 below traces the evolution of lending rates in Brazil since 1997. Only in 2013, as a result of a credit boom fueled mostly by public banks' lending, did borrowing rates for small and medium-sized enterprises descend from $30 \%$ per year, in nominal terms (inflation has rarely topped double digits during this period).

There is no simple explanation for the pattern in Figure 1. Credit as a percentage of GDP has more than doubled in the last 20 years, so financial repression alone cannot justify it. For the purpose of carefully analyzing the econometric evidence from Brazilian credit markets, we start the present study by describing the recent evolution of the country's financial system. The possible determinants of credit spread include the market microstructure,

Submitted on May 14, 2020. Revised on August 10, 2020. Accepted on August 10, 2020. Published online in December 2020. Editor in charge: Marcelo Fernandes.

${ }^{\dagger}$ New York University - Shanghai \& Fundação Dom Cabral - Brazil: rodrigo . zeidan@nyu . edu 
Figure 1

Lending rate (\% per year), Brazil, 1997-2019

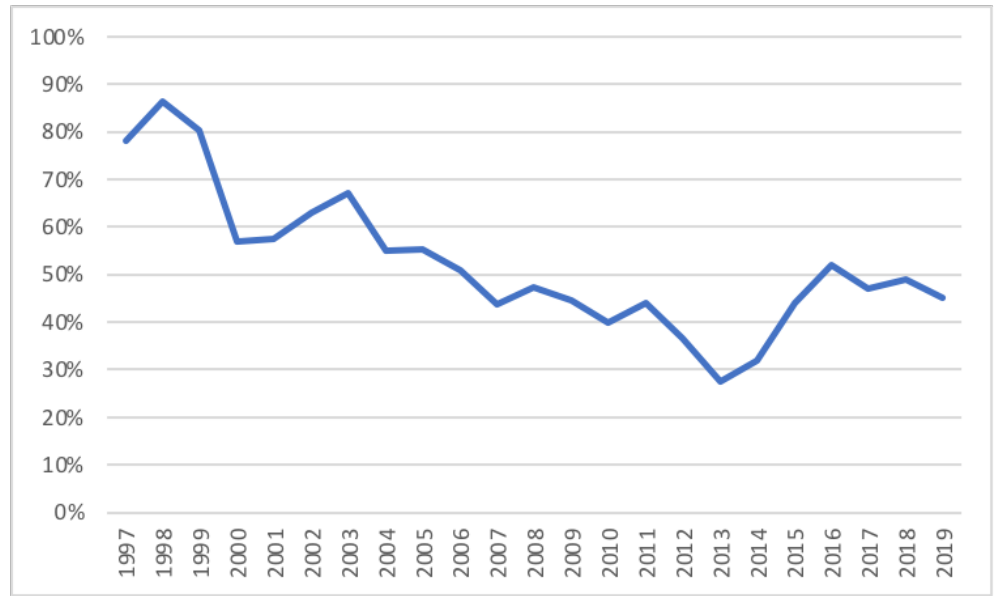

Source: World Bank and Central Bank of Brazil, 2020.

operating costs, credit risk, opportunity costs, managerial quality, nominal interest rates (SELIC), market concentration, interest rate volatility, earmarked credit, and GDP.

Results from econometric studies are clear-cut in one aspect: market concentration is consistently and statistically significant in all studies. Since researchers cannot observe tacit or explicit collusion directly, market concentration is the usual proxy for (un)competitive behavior. We posit that higher concentration is part of a well-defined strategy by the Central Bank of Brazil: prudence over efficiency. We describe how the Brazilian financial crisis of the mid-1990s has tightened financial regulation in Brazil and how the Central Bank has overseen a consolidation process in the credit market - the share of the five largest lenders, as measured by the total assets held by these institutions over the total assets of the industry, has climbed from 50\% in 2000 to more than $80 \%$ in 2019.

There is some silver lining, however. Since 2017, the Central Bank has somewhat eased regulations for new credit companies, including fintechs. In December 2018, the monetary authority gave permission to the first fintech company to hand out credit. Reserve requirements have been steadily falling. Changes in the market structure of credit markets have accelerated due to the COVID-19 crisis, which has frozen credit in many parts of the world, including Brazil. It may be that this crisis will speed up the process of financial reform that will finally bring down credit spread in the country. 
Figure 2

Lending rates, deposit rates and interest rate spread, Brazil, 1997-2019

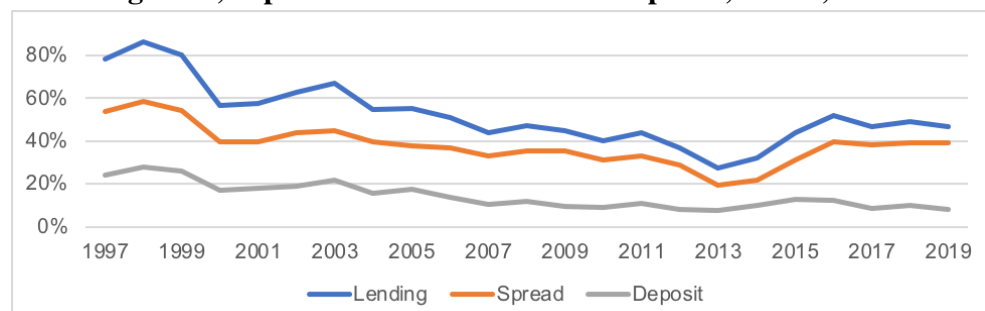

Source: World Bank (2019) (https : / /data.worldbank . org/indicator/FR. INR. LEND) and the Central Bank of Brazil (2019) (https: / /www.bcb.gov.br/content/publicaco es/relatorioeconomiabancaria/\%20reb_2018.pdf).

The rest of the article is divided as follows: the next section traces the evolution of Brazilian credit markets since the end of the hyperinflation era in the mid-1990s; the third section describes which variables could drive credit spreads; and the last section summarizes the econometric results found in the scientific literature.

\section{Brazilian credit markets}

Credit in Brazil has four salient features. It is scarce, expensive, concentrated, and segmented. In addition, state-owned banks play a significant role. The market has changed somewhat in the last 10 years. The Brazilian federal funds rate has steadily declined, from 13\% in 2010 to $3 \%$ as of May 2020. Other changes in credit markets, such as the arrival of fintech companies (first authorized to perform credit operations in December 2018), indicate that Brazilian financial markets may be becoming less inefficient. Yet in its most relevant outcome, lending rates to households and SMEs, nothing much has changed; Brazil remains the country with some of the highest lending rates in the world, 25 years after the successful stabilization plan of 1994, Plano Real, which ended a decade of hyperinflation.

Figure 2 shows data on nominal deposit rates, lending rates, and the credit spread, from 1997 to the present.

Geometric means for lending, deposit and inflation rates, and interest rate spreads are shown in Table 1.

Data refer to three distinct periods: the Cardoso era (1995-2002); the Workers Party era (2003-2014); and the current era (2015-2019). As we can see from Table 1, if we take a long-term view of the evolution of the Brazilian credit markets, lending rates have declined in the last 25 years in real terms, since inflation has averaged between $5 \%$ and $6 \%$ a year throughout 


\section{Table 1}

Interest rates spread and lending, deposit and inflation

rates, Brazil, 1997-2002, 2003-2014, 2015-2019

\begin{tabular}{lrrr}
\hline & $1997-2002$ & $2003-2014$ & $2015-2019$ \\
\hline lending & $69 \%$ & $44 \%$ & $48 \%$ \\
spread & $48 \%$ & $32 \%$ & $37 \%$ \\
deposit & $22 \%$ & $12 \%$ & $10 \%$ \\
inflation & $6 \%$ & $6 \%$ & $5 \%$ \\
\hline
\end{tabular}

Source: Central Bank of Brazil (2019).

Figure 3

Nominal Lending rates in selected South American countries, 1997-2018

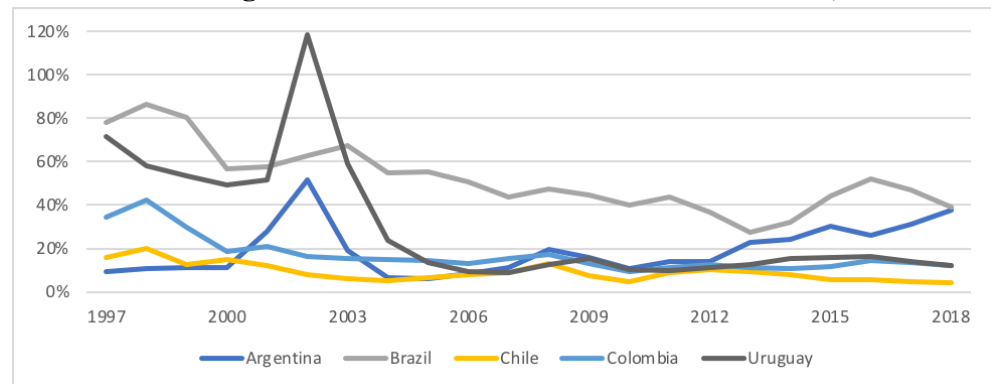

Source: World Bank (2019) $)^{2}$.

the period. Deposit rates have fallen the most, but real lending rates are still astronomically high, at $30 \%$ a year. For comparison, other than Uruguay in 2002, when the country faced a financial crisis, lending rates in Brazil have been, by far, the highest in South America, since 1997 (Figure 3). Even in Argentina, where inflation was $24 \%$ in 2017 and $47 \%$ in 2018, lending rates have been lower, in nominal terms, than in Brazil, where prices increased by less than 3\% per year in 2017 and 2018. ${ }^{1}$ In nominal or real terms, lending rates in Brazil are a worldwide outlier.

Since credit is expensive in Brazil, it should come as no surprise that domestic credit to the private sector, as a percentage of GDP, lags behind other middle-income countries, although it is not out of line with some other countries in Latin America. Factors such as macroeconomic instability, large size of the economy, political instability and other institutional characteristics may explain why credit is not higher in Brazil and the rest of Latin America

\footnotetext{
${ }^{1}$ The sample of countries used for cross-country comparisons changes because of data availability. Regardless, comments in the text are robust, unless noted, to the selection of other comparable countries.
} 
Figure 4

Domestic credit to private sector (\% of GDP)

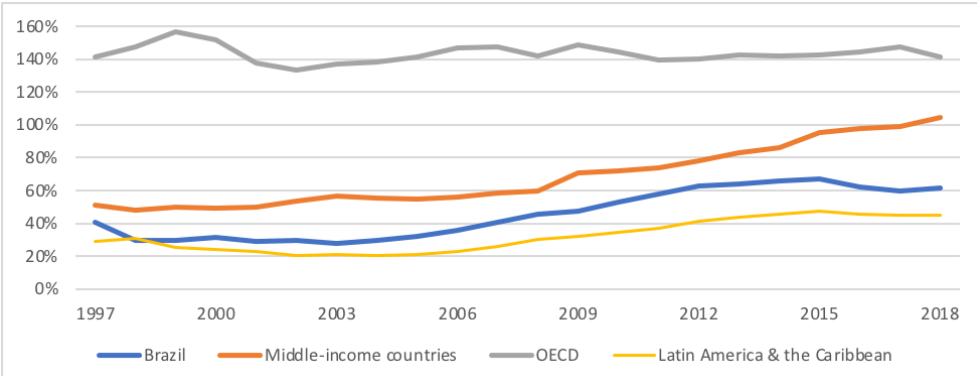

Source: World Bank (2019).

(Figure 4).

Companies issued $\mathrm{R} \$ 200$ billion of corporate bonds in 2018 , or $2.9 \%$ of GDP, and R $\$ 24$ billion in new equity, a meager $0.35 \%$ of GDP. The stock of non-financial corporate debt is around 25\% of GDP (CVM; 2018), while total nonfinancial corporate debt, including loans and debt securities, hovers around 40\% (having not changed much since the 1990s; and the latter ratio includes some commercial bank funding; see Figure 5). Moreover, stock market capitalization is approximately $46 \%$ of GDP (CEIC, 2019), a figure that would be much lower if we were to disregard state-owned companies. Of course, most other Latin American countries share some of these features. Stock market capitalization is a bit over 30\% of GDP in Mexico and $37 \%$ in Colombia, while, for the latter, the stock of non-financial corporate debt is $30 \%$ of GDP.

Since 2000, the banking industry has become heavily concentrated. The five-bank asset concentration has increased from 50\% in 1997 to $85 \%$ in 2019 (Figure 6).

We explore the reasons for this increased concentration in Section 3. Bank credit is not only concentrated in a few banks, but also features state-owned banks prominently. In the 2010s, banking loans grew mostly because of stateowned banks, a result of a concerted political effort that has backfired, leading to the share of credit from state-owned banks to return somewhat to its previous level (Figure 7).

Figure 7 also illustrates the insignificant role played by foreign banks in Brazilian credit markets. Foreign banks provide less than half the credit in Brazil than in other emerging markets, where foreign banks' credit averages 15-20\% of total credit (Hardy; 2019). That has not always been the case. There have been two waves of entry and exit of foreign banks in Brazil. After 


\section{Figure 5}

Nonfinancial corporate debt, loans and debt securities (\% of GDP)

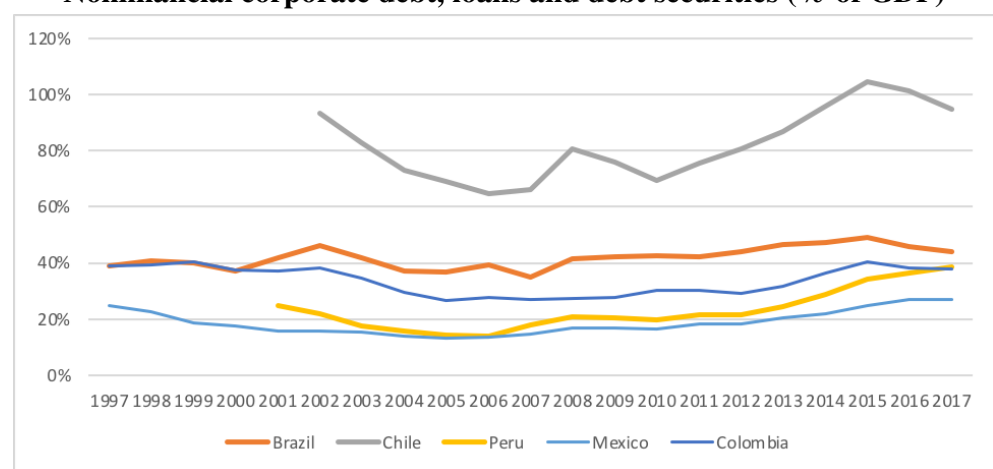

Source: IMF (2019).

Figure 6

5-Bank Asset Concentration for Brazil, Percent, Annual

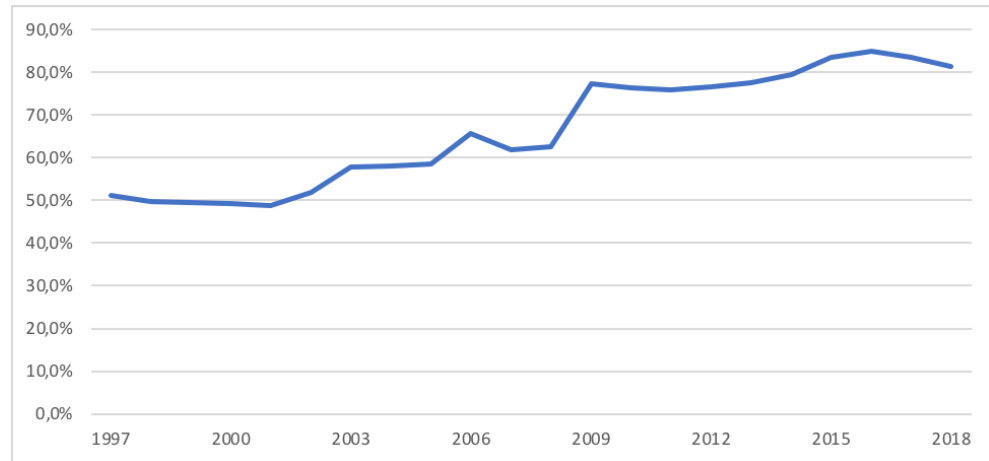

Source: World Bank (2019) and Central Bank of Brazil (2019). 
Figure 7

Credit operations outstanding by type of ownership, \% of GDP, monthly

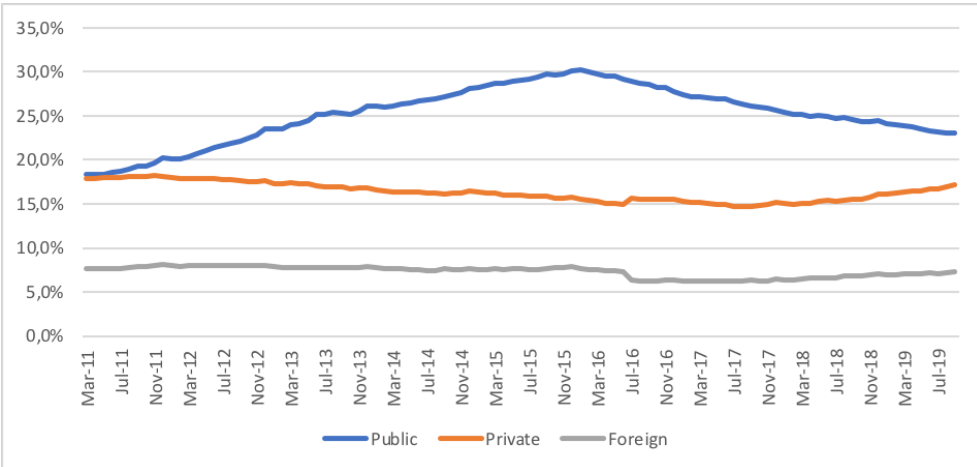

Source: Central Bank of Brazil, 2019.

a large-scale entry in the late 1990s, banks had already retreated by the mid2000s (Fachada; 2008), and for the 2011-2019 period (Figure 7) data reflect the status quo of a mostly local capital credit market.

Unlike the Brazilian experience in the past, and in developed countries in the late 2000s, the rapid expansion of the credit system in Brazil after 2004 has not increased financial fragility (Torres Filho et al.; 2014). The flipside of the induced concentration is a stable (and modern) regulatory framework, in which financial crises are unlikely. Take the case of Itaú, for instance. Its regulatory required equity in 2020 is $\mathrm{R} \$ 83$ billion (Itaú; 2020, p.11). But the bank's matching equity is $\mathrm{R} \$ 139$ billion, a surplus of more than $66 \%$ (in some years, the buffer is higher than 100\%). Data on regulatory capital to risk-weighted assets data (Figure 8) show that since 2002, Brazilian banks hold significant excess capital over the $11 \%$ Basel III threshold that includes countercyclical buffers (for Itaú, this buffer is $\mathrm{R} \$ 36$ billion in 2020).

The conservative approach to regulation does not change if we trace the evolution of banks' liquidity ratios over time. The Basel III accord has set a minimum requirement on the liquidity coverage ratio (LCR) at $60 \%$ starting on January 1, 2015 and rising by 10 percentage points annually to reach $100 \%$ on January 1, 2019. In Brazil, since 2006, the LCR has never been below $140 \%$. For privately-owned Brazilian banks, the LCR, at its lowest, was $120 \%$ in 2012 (Figure 9). In 2019, the LCR for Brazilian banks averaged 240\%, much higher than the updated minimum requirements, and $100 \%$ above the average in the OECD.

The last descriptor of credit market outcomes is segmentation. Credit in Brazil is divided into earmarked and non-earmarked. Earmarked credit 
Figure 8

Regulatory Capital to Risk-Weighted Assets - \%, monthly

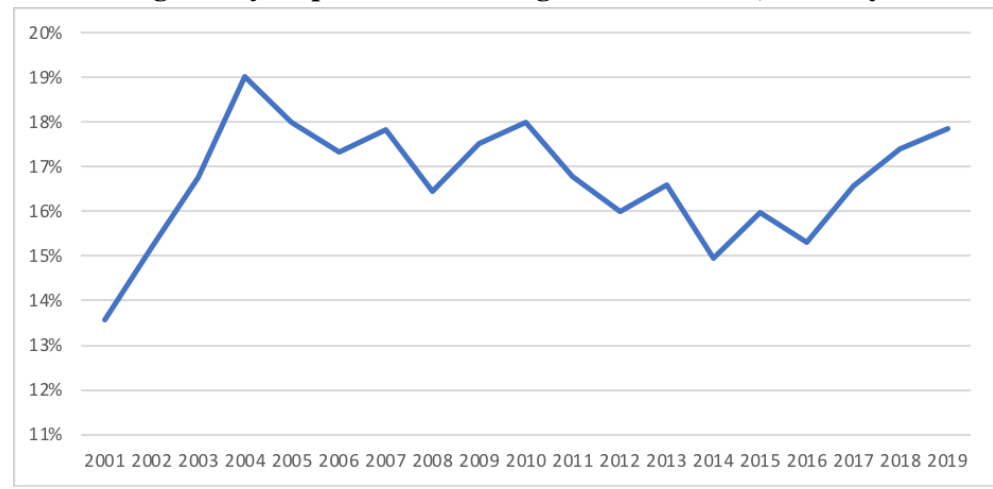

Source: Central Bank of Brazil, 2019.

Figure 9

Brazilian Banking System Liquidity Coverage Ratio - Index - \%, monthly

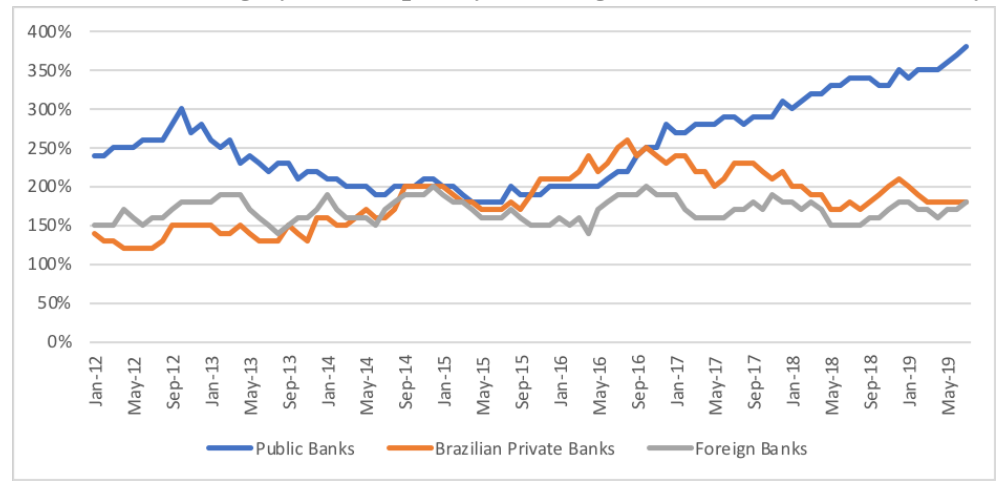

Source: Central Bank of Brazil, 2019. 
Figure 10

Credit operations outstanding, earmarked and non-earmarked, \% of GDP, monthly

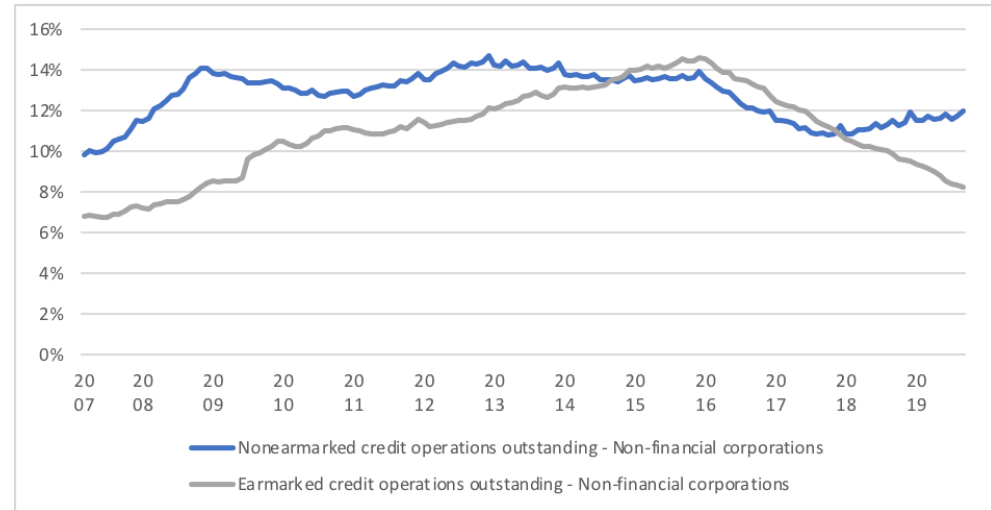

Source: Central Bank of Brazil, 2019.

from bank deposits includes mandatory lending to agriculture, microfinance, poor households, and mortgages. Some directed credit face interest rate caps. The largest development bank in the country, BNDES (Banco Nacional de Desenvolvimento Econômico e Social), the main source of earmarked bank credit for corporations, is also funded mainly through quasi-fiscal funds and government transfers, but not from deposits or from issuing its own bonds.

Figure 10 illustrates that almost all credit growth in the country since 2007 , as a $\%$ of GDP, has been due to earmarked credit, both to non-financial corporations and households - mostly housing. Since 2016, there has been a retreat in earmarked credit to non-financial corporations, but this type of credit is still relatively important as a share of total outstanding loans.

Differences between earmarked and non-earmarked credit are not due solely to lower interest rates in earmarked loans. Average term to maturity of new credit operations is significantly higher in proportion to non-earmarked credit, both to non-financial corporations and households (Figure 11).

Figure 11 shows that only the maturity of earmarked credit to households has increased since 2011. Historically, large quasi-fiscal funds have funded almost all long-term loans to industry, infrastructure, and housing (Torres Filho et al.; 2014). As financial markets mature, private credit should substitute publicly earmarked credit, with institutions such as development banks specializing and shrinking (Torres and Zeidan; 2016). Nevertheless, timing matters. Since 2017, the Brazilian governments have reduced BNDES funding, amidst a severe recession, a move that most likely has contributed to a 
Figure 11

Average term to maturity of new credit operations, number of months, monthly

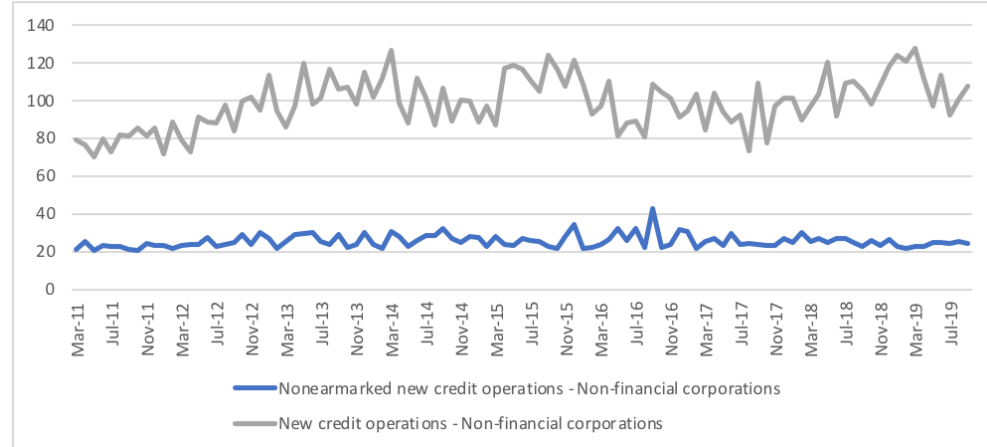

Source: Central Bank of Brazil, 2019.

slow macroeconomic recovery.

Earmarked credit may reduce the ability of banks to lend freely to consumers and corporations. But this is unlikely to be as important as the fact that reserve requirements in Brazil have been among the highest in the world in the last 25 years. For the better part of the 2010s, reserve requirements have been $45 \%$ for spot deposits. They started falling in late 2017, but are still among the highest in the world, at $21 \%$ as of May 2020.

Figures 1-10 summarize the main outcomes of Brazilian credit markets. Throughout the first two decades of the $21^{\text {st }}$ century, credit markets have become more concentrated, earmarked credit has grown and retreated, reserve requirements have been scaled down somewhat, and credit has breached $60 \%$ of GDP for the first time. Still, credit in Brazil is scarce and expensive, arguably the most expensive in the context of middle-income countries. Interest rate spreads are around $40 \%$ a year, which is incompatible with mature and efficient capital markets.

There is some silver lining, however. Interest rate volatility has come down dramatically since 2016. Since 2017, the Central Bank has somewhat eased regulations for new credit companies, including fintechs, allowed to lend since December 2018. Reserve requirements have been steadily falling. In early 2020, the COVID-19 crisis has shown how expensive credit is a major barrier to efficient capital markets. The reaction from the Central Bank to this crisis may speed up the process of financial reform that will finally bring down the price of credit in the country.

Now that we have presented the context of Brazilian credit markets and preliminary evidence on the determinants of lending rates in the country, we 
move to answer the question: why are spreads so high in Brazil?

\section{What drives interest rate spreads}

\subsection{Modeling bank spreads}

Bank spreads are the difference between banks' borrowing costs and final lending rates. Basic economic theory tells us that spreads can be kept high only through some sort of dynamic restriction on supply, or if other costs are perennially steep. Hence, there are two possible complementary explanations. Persistent spreads could be driven by either non-performing loans, reserve requirements, taxes, and administrative costs or persistent profits from imperfectly competitive markets. A classic oligopolistic market with persistent barriers to entry could explain the extreme bank spreads in Brazil.

Nevertheless, modeling bank spreads is not straightforward. The supply and demand functions for lending are not clearly identified. For instance, in the previous section we saw that earmarked credit and reserve requirements in Brazil are relatively high. Yet it is hard to figure out if earmarked credit crowds out or crowds in private lending. It could very well be the case that earmarked credit in an underdeveloped financial system allows long-term projects to be funded, and in turn these projects, which otherwise would not exist, affect credit demand and supply. If that were the case, earmarked credit would stimulate investment and could potentially reduce long-term banking spreads. It is likely that earmarked credit directly reduces credit supply, increasing bank spreads, by lowering the amounts available for banks to lend, at least in the short run, but no comprehensive model of bank spreads exists.

Such a model would have to allow for the evolution of market efficiency. Generally, interest rate spreads are a good proxy for financial intermediation efficiency. In that sense, persistently high spreads are indicative of inefficient financial markets. Since the institutional background is ever-evolving, modeling bank spread over time requires that the evolution of financial markets are taken into account.

Souza-Sobrinho (2010) provides a general equilibrium model with nineteen parameters calibrated to the Brazilian economy of the 2000s, grouped into four categories: preferences, firm technology, banking, and policy. Interestingly, the author incorporates high reserve requirements and cross-subsidies that end up accounting for almost half of the spread level in the model and a third of the actual spread level.

The baseline model has discrete time in a closed economy without restrictions to factor mobility, and all markets being competitive. A representative household owns the shares of firms and banks, and there is just a single corpo- 
rate credit market for tractability. Two economic sectors produce intermediate goods, depending on physical and financial inputs. Finally, the government pays an interest rate on reserves, and rebates any proceeds to households in a lump-sum.

In equilibrium, only Sector 1 is offered and accepts loans from banks and, additionally, borrows in the free credit market. Results indicate that eliminating reserve requirements yields a welfare gain of $1.2 \%$ of current consumption, whereas eliminating credit requirements implies a gain of $0.4 \%$. Moreover, bank spreads decrease by half.

The model by D'erasmo (2016) complements Souza-Sobrinho (2010). While the latter focuses on the welfare gains of more efficient credit markets on bank spread, bank performance and allocation of resources in the long run, the former establishes a connection between credit conditions, the level of formalization, and the firm size distribution.

The model is also a general equilibrium model. It features informal and formal sectors, and firms make capital financing and bankruptcy decisions. It is not a closed economy model, and financial intermediaries have access to international markets at the risk-free rate.

The goal of the model is to analyze "the effect of a 37 percent reduction in the cost of funds for financial intermediaries (from 7.5 to 4.7 percent) and a 44 percent reduction in the cost of issuing loans (from 5.58 to 3.31 percent)" (p.145). To achieve that effect, the following happen: changes in intermediation costs affect corporate bond prices and lower default probabilities; incumbent firms adjust the relation between debt and capital; incentives to borrow become stronger; and the endogenous entry and exit productivity thresholds change. Firms' valuations increase, which reduces the entry threshold into formalization. More entry, and exit, induces competition and higher wages.

These two models (and their empirical results) are mostly in agreement with the stylized facts of the previous section. Credit restrictions have potential welfare impacts on households' consumption and total factor productivity. The models do not identify all the variables affecting high spreads. To delve into the specifics of the credit restrictions, we turn to empirical evidence, from simple accounting decomposition and econometric estimation.

\subsection{Accounting decomposition}

The Central Bank of Brazil has published, since 2017, banking spread decompositions based on financial reporting and regulatory access to detailed data from financial institutions. The spread decomposition exercise is based on the average cost of outstanding loans (ICC), which is an estimate of the average cost of credit for outstanding operations from the borrower's perspec- 
tive. The ICC includes information from both recent and previous outstanding contracts (Central Bank of Brazil; 2017).

The spread (over funding costs) decomposition includes four categories: non-performing loans, administrative expenses, taxes and contribution to the credit guarantee fund, and profits. Over the 2015-2017 period, non-performing loans account for $37 \%$ of the spread, followed by administrative expenses (25\%), taxes and contributions to the credit guarantee fund (23\%), and profits (15\%) (Central Bank of Brazil; 2017).

This accounting exercise is informative, but not definitive. It does not consider the dynamics of borrowing costs over time. There are also estimations regarding the indirect opportunity costs of earmarked credit. PazarbasiogluDutz et al. (2017) find that "the fiscal cost of explicit and implicit subsidies amounts to about 3.7 percent of general government revenue (1.5 percent of GDP) for 2015," mostly because of "the differential between regulated rates and market interest rates at which the government finances its lending" (p.1). Moreover, "savers and employees each contribute about 0.3 percent of GDP to lowering interest rates on earmarked credit. The savers and employees receive low remuneration on deposits and contributions to FGTS, respectively" (p.1). Of course, there are firms that benefit from these subsidies. The authors find that companies in the services, rural, and energy sectors, and larger, older and less risky firms profit the most. As for households, benefits are concentrated in those with access to rural credit and mortgage loans.

Again, results are in line with the previous section. Earmarked credit may contribute to high spreads in Brazil but that is unlikely, and accounting decomposition cannot answer to which extent this happens, or even if there is the possibility of crowding in of private investments, given earmarked credit.

\section{Empirical evidence on economic drivers of banking spreads}

Brazil's high interest rates have long been a puzzle (Segura-Ubiergo; 2012) and the country has been through decades of failed strategies to reduce spreads (da Silva and Pirtouscheg; 2015). In 2020, nominal interest rates have fallen to historically low levels (3.0\%) but banking spreads have not followed suit.

Empirical modeling of credit markets is not straightforward. As Coelho et al. (2017) observe, it is hard to find exogenous variation for the estimation of credit supply and demand, as there are variables, such as the cost of funds, that are present in both demand and supply functions. Even so, evidence from global markets favors the role of imperfectly competitive markets in driving banking spreads. Costs explain some of cross-country differences in banking spreads, but not all of them. For instance, Hawtrey and Liang (2008) find that national industry margins are influenced by market power, operational cost, 
risk aversion, interest rate volatility, credit risk, volume of loans, implicit interest payments, and quality of management. Valverde and Fernández (2007) explore the role of market power in determining bank margins in Europe. In traditional credit markets, more competition induces lower margins, and banks may even compensate negative margins in credit operations by using their market power related to services and other non-credit operations. More competition leads to lower margins in credit markets, as expected.

\subsection{Empirical results regarding bank spreads in Brazil}

For Latin America, but not Brazil, Brock and Suarez (2000) are the first to analyze spread determinants. Their work is important for its focus on properly measuring bank spreads. While conceptually the banking spread concept is simple, a cross-country comparison is not straightforward. The authors use "six alternative proxies for bank spreads, ranging from a narrow concept one that includes loans in the asset side and deposits in the liability side to a broad concept where all interest earning assets and liabilities plus associates fees and commissions are included." (p.121) They use the following six proxies:

1. (interest received/loans)-(interest paid/deposits);

2. (interest received/all interest-bearing assets)-(interest paid/all interestbearing liabilities);

3. (interest plus commissions received/loans)-(interest paid plus commissions paid/deposits);

4. (interest plus commissions received/all interest-bearing assets)-(interest plus commissions paid/all interest-bearing liabilities);

5. (interest received on loans only/loans)-(interest paid on deposits only/deposits);

6. (interest received-interest paid)/total assets.

Brock and Suarez (2000) use simple panel data OLS estimations and find that the liquidity coverage ratio is more important than non-performing loans to explain high spreads in Latin America.

Gelos (2009) revisits banking spreads in Latin America, introducing legal framework and creditors' rights as variables that explain borrowing costs. As we can see in Figure 12, Latin America is the region with the weakest credit legal rights index. The strength of legal rights index measures "the degree to which collateral and bankruptcy laws protect the rights of borrowers and lenders and thus facilitate lending" (World Bank; 2019). ${ }^{3}$

${ }^{3}$ In addition, "the index ranges from 0 to 10 , with higher scores indicating that laws are better 
Figure 12

Strength of legal rights index $(0=$ weak to $12=$ strong $)$

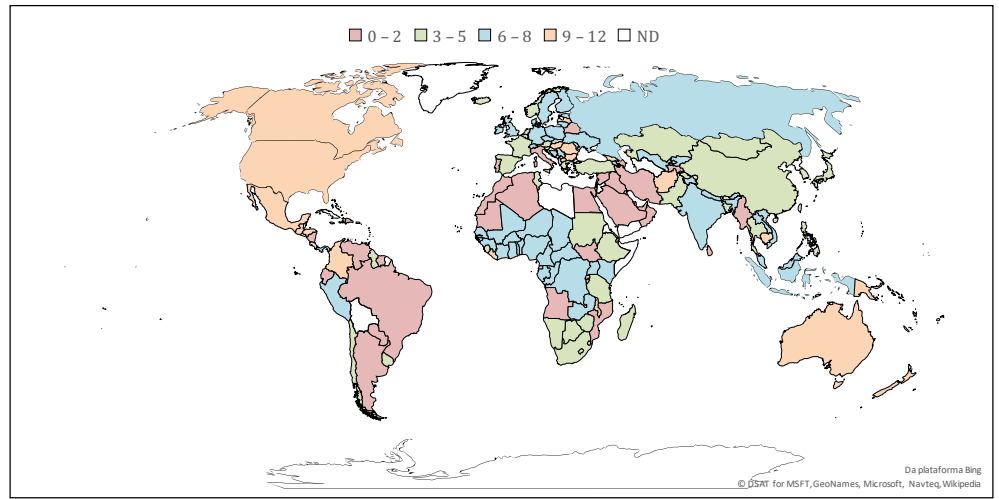

Source: World Bank, 2019. ND = No Data.

It is likely that earlier studies do not include measures of creditors' rights because of a lack of data. Gelos (2009) incorporates creditor rights and the legal framework in a simple regression in which ex-post net margin is the dependent variable and exogenous variables are proxies for several elements: creditor rights, macroeconomic volatility, competition in the banking sector, reserve requirements, the level of interest rates, taxation of the financial sector, and availability of information about borrowers. The sample includes Latin American countries and data encompass the 1999-2002 period. The expost net margin is defined as interest income minus interest expense divided by interest-bearing assets. The author finds that, at the country level, "the level of interest rates and reserve requirements are strongly positively associated with higher spreads, while the correlation with GDP growth is negative." In addition, "a fall in the deposit rate of 1 percentage point would be associated with a drop in net interest margins by $0.1-0.2$ percentage points; and a reduction in reserve requirements on demand deposits by 10 percentage points would reduce net interest margins by an average of $0.4-0.7$ percentage points" (p. 805). GDP growth is negatively associated and five-bank concentration is positively associated with net margins. Results broadly confirm the stylized facts in Section 2: "in comparison to other developing countries,

designed to expand access to credit. Specifically, up to 8 points are awarded for aspects of collateral law and up to 2 points are awarded for aspects of bankruptcy law. Data is gathered through a survey of financial lawyers and then verified through analysis of laws and regulations as well as public sources of information" (World Bank - Doing Business: https : / www . do ingbusiness.org/). 
spreads in Latin American banking markets are likely to be higher because of less efficient banks, weaker competition, higher levels of interest rates, higher reserve requirements, and a less supportive legal environment."

Evidence indicates that direct and indirect non-borrowing costs do explain some, but not all, of the credit spread in Brazil.

Almeida and Divino (2015) estimate a straightforward panel data OLS (the static model) and a GMM (the dynamic model) on a sample of 64 banks in Brazil. Their proxy of spread is the net interest margin of the banks and they regress it on a constant representing the pure spread, a liquidity index, administrative expenses, revenue from services, a coverage index, tax expenses, credit risk, market share, management quality, opportunity cost, implicit interest rate payment, market concentration, and macroeconomic variables. They find that "administrative expenses, revenue from services and coverage index are important determinants of the ex-post spread. The macroeconomic environment showed positive effects arising from real GDP while the Herfindahl-Hirschaman index indicated that spreads are higher for a more concentrated banking system. The dynamic model revealed a moderate persistence of the ex-post banking spread and a relevant role for the banks' market-share" (p. 29).

Their results differ from Dantas et al. (2012) in relation to administrative costs. Dantas et al. (2012) do not find statistical significance for administrative expenses, revenue from operations, and coverage, but find that concentration, credit risk and GDP partially explain high banking spreads in Brazil. Interestingly, and expectedly, there is no difference in any of these factors for public, private, and foreign banks. This is in line with the stylized facts of the previous section, in which scarce and expensive credit are market- but not firm-specific.

Additional evidence of market-wide factors that influence interest rates is given by Alencar (2011) and Jorgensen and Apostolou (2013).

Alencar (2011) concentrates on the pass-through of monetary price to corporate (vendor and working capital) and retail (personal, auto and other goods) loans. Estimates for short- and long-term pass-through are positive and significant. The author finds that macroeconomic variables such as interest rate volatility, inflation, and income growth affect both corporate and retail loans. More importantly, default rate and market concentration are strongly positive and significant drivers of all types of loans, while liquidity and funding inefficiency are less significant.

Jorgensen and Apostolou (2013) control the net interest margin for the implicit interest expense, the opportunity cost of required reserves, and capital requirements for credit-risk exposure. The other institutional effects and 
Table 2

Empirical results on banking spreads

\begin{tabular}{|c|c|c|c|c|c|c|c|c|c|}
\hline \multirow[b]{3}{*}{$\begin{array}{l}\text { Hawtrey and } \\
\text { Liang (2008) } \\
\text { - OECD }\end{array}$} & \multicolumn{2}{|c|}{ endogenous } & \multicolumn{4}{|c|}{ micro } & \multicolumn{3}{|c|}{ macro } \\
\hline & & $\begin{array}{c}\text { market } \\
\text { Structure }\end{array}$ & $\begin{array}{c}\text { operat. } \\
\text { costs }\end{array}$ & credit risk & $\begin{array}{c}\text { opport. } \\
\text { costs }\end{array}$ & $\begin{array}{l}\text { manag } \\
\text { quality }\end{array}$ & int. rate & int. rate $\sigma$ & GDP \\
\hline & NIM & + & + & + & + & + & $\mathrm{n} / \mathrm{a}$ & + & $\mathrm{n} / \mathrm{a}$ \\
\hline Gelos (2009) & NIM & + & + & 0 & + & $\mathrm{n} / \mathrm{a}$ & + & $\mathrm{n} / \mathrm{a}$ & - \\
\hline $\begin{array}{l}\text { Dantas et al. } \\
\text { (2012) }\end{array}$ & $\begin{array}{l}\text { ex-post } \\
\text { spread }\end{array}$ & + & 0 & + & $\mathrm{n} / \mathrm{a}$ & $\mathrm{n} / \mathrm{a}$ & 0 & $\mathrm{n} / \mathrm{a}$ & + \\
\hline $\begin{array}{l}\text { Almeida and } \\
\text { Divino (2015) }\end{array}$ & $\begin{array}{l}\text { ex-post } \\
\text { spread }\end{array}$ & + & + & 0 & 0 & 0 & 0 & 0 & + \\
\hline $\begin{array}{l}\text { Da Silva and } \\
\text { Pirtouscheg } \\
\text { (2015) }\end{array}$ & $\begin{array}{l}\text { lending } \\
\text { rate }\end{array}$ & + & $\mathrm{n} / \mathrm{a}$ & + & $\mathrm{n} / \mathrm{a}$ & $\mathrm{n} / \mathrm{a}$ & + & $\mathrm{n} / \mathrm{a}$ & 0 \\
\hline $\begin{array}{l}\text { Jorgensen and } \\
\text { Apostolou } \\
\text { (2016) }\end{array}$ & NIM & + & + & $\mathrm{n} / \mathrm{a}$ & + & $\mathrm{n} / \mathrm{a}$ & + & + & $\mathrm{n} / \mathrm{a}$ \\
\hline
\end{tabular}

frictions are reflected in a residual variable. More important, and as expected given the contextual information from the market and previous econometric results, the main drivers of spreads in Brazil are related to microeconomic and competition factors, while macroeconomic variables, even though significant, play a minor role. Microeconomic variables, for Jorgensen and Apostolou (2013), explain $79 \%$ of bank spreads, with competition explaining $17 \%$, and macroeconomic factors only $4 \%$.

Coelho et al. (2017) find that Brazilian consumer credit demand is quite interest-rate inelastic, firm credit demand is elastic, and credit supply is elastic, results that are in line with others in this and the previous section.

Finally, the most recent and compelling evidence for the role of concentration in explaining spread comes from Joaquim et al. (2019). The authors use heterogeneous exposure to large bank mergers, using detailed administrative data on loans and firms and employing a difference-in-differences empirical strategy to identify the causal effect of bank competition on certain variables, including spreads. They find that following M\&A episodes, spreads increase and lending is reduced, persistently. Moreover, reduced bank competition from concentrated markets has real effects: a $1 \%$ increase in spreads leads to a $0.2 \%$ decline in employment. The authors also build a counterfactual scenario in which, if the Brazilian lending spread were to fall to the world level, output would increase by approximately $5 \%$.

In the end, evidence on administrative costs is mixed, but that of an imperfectly competitive market is robust. Market concentration and other proxies 
for oligopolistic behavior explain a good part of credit spreads. Moreover, it is the only variable that is always found to be statistically significant. There is little question that the oligopolistic nature of Brazilian credit markets are one, if not the main, reason for expensive credit in the country.

\subsection{Credit rationing, intermediation costs and the bank channel of mon- etary policy}

Banking spreads in Brazil may be driven by the market structure, earmarked credit, funding costs and, less importantly, macroeconomic factors. In Section 4.1 we saw how scarcity and intermediation costs generate welfare losses. In this section, we explore one last relation between bank spreads, credit scarcity and welfare: the transmission of monetary policy.

The twin sources of inefficiency: high interest rates and high banking spreads, reduce the ability of monetary authorities to conduct monetary policy. Unsurprisingly, low-income countries have weaker transmission of monetary policy than high-income and emerging economies (Mishra et al.; 2014). Moreover, financial repression and intermediation costs may significantly hamper growth (Antunes et al.; 2008).

Here we argue that the bank channel of monetary policy, or how lending supply responds to changes in money supply, in Brazil, a middle-income country since the 1970s, is as weak as in low-income countries. Financial repression and intermediation costs, as shown in previous sections, coupled with the dysfunctional bank channel, mean that lower interest rates, as the country has experienced lately, should not result in improved economic activity.

Ramos-Tallada (2015) provides the most comprehensive study of the bank channel of monetary policy in Brazil. The author establishes a micro-founded estimation strategy to estimate the bank lending channel in Brazil (BLC). The author finds that lending supply is negatively correlated with the shortterm market interest rate, but only in the period before the financial crisis for the average bank. Yet small banks and those lacking access to long-term funds sometimes appear sensitive to monetary shocks. Surprisingly, there is evidence that the credit demand by foreign banks is more resilient than local banks, maybe due to global rather than local monetary conditions. Therefore, Ramos-Tallada (2015) provides the first evidence that foreign banks in Brazil behave differently than local banks (of the studies in Table 2, all that control for ownership fail to find any indication of distinct firm behavior).

Ramos-Tallada (2015) also finds that the higher the ex-ante systematic market risk and the lower the volatility of market rates, the stronger the bank lending channel. The first measure is captured through the duration of out- 
standing marketable public securities. In a benign scenario of low and nonvolatile interest rates, but with low systemic risk, as in Brazil in 2019, it is unclear which effect would be more relevant.

Another study on the bank lending channel (BLC) of monetary transmission (using data from the 2006-2012 period) is that of Bonomo and Martins (2016). Using data on corporate loan contracts of 300,000 non-financial firms between 2006 and 2012, they find that the credit channel of monetary policy is less effective for firms with government-driven loan access. Of course, the flip side is that government-driven loans allow companies to better insulate themselves from the effects of external shocks.

\section{Final comments}

Brazilian credit is the most expensive in the world, as measured by the spread between deposit and lending rates. In this article we summarize the academic literature and provide an explanation for this particular feature of Brazilian financial markets.

Credit as a percentage of GDP has more than doubled in the last 20 years, so financial repression alone cannot explain it. We explore the role of the market microstructure, operating costs, credit risk, opportunity costs, managerial quality, nominal interest rates (SELIC), market concentration, interest rate volatility, earmarked credit, and GDP in explaining credit spreads in Brazil. We find that market concentration is consistently statistically significant in econometric studies on the determinants of credit spreads in the country. Since researchers cannot observe tacit or explicit collusion directly, market concentration is a major proxy for (un)competitive behavior. We posit that higher concentration is part of a well-defined strategy by the Central Bank of Brazil: prudence over efficiency. We describe how the Brazilian financial crisis of the mid-1990s has tightened financial regulation in Brazil and how the Central Bank has overseen credit markets consolidating into a few players - the share of the large five lenders, as measured by the total assets held by these institutions over the total assets of the industry, climbed from $50 \%$ in 2000 to more than $80 \%$ in 2019.

There is some cause for optimism, however. Since 2017, the Central Bank has somewhat eased regulations for new credit companies, including fintechs. The first fintech company was allowed to operate credit products starting in December 2018. Reserve requirements have been steadily falling. In early 2020, the COVID-19 crisis has reminded Brazilian regulators that expensive credit is a major barrier to efficient capital markets. It may be that this crisis will speed up the process of financial reform that will finally bring down credit spread in the country. 


\section{References}

Alencar, L. S. (2011). Revisiting Bank Pricing Policies in Brazil: Evidence from loan and deposit markets, Working Papers Series 235, Central Bank of Brazil, Research Department.

URL: https : / /www.bcb.gov.br/pec/wps/ingl/wps235.p df

Almeida, F. D. and Divino, J. A. (2015). Determinants of the banking spread in the Brazilian economy: The role of micro and macroeconomic factors, International Review of Economics \& Finance 40: 29-39.

Antunes, A., Cavalcanti, T. and Villamil, A. (2008). The effect of financial repression and enforcement on entrepreneurship and economic development, Journal of Monetary Economics 55(2): 278-297.

Bonomo, M. and Martins, B. (2016). The Impact of Government-Driven Loans in the Monetary Transmission Mechanism: What can we learn from firm-level data?, Working Papers Series 419, Central Bank of Brazil, Research Department.

URL: https: / /www . bcb.gov.br/pec/wps/ingl/wps419.p df

Brock, P. L. and Suarez, L. R. (2000). Understanding the behavior of bank spreads in Latin America, Journal of Development Economics 63(1): 113134.

Central Bank of Brazil (2017). Banking Report, Technical report, Central Bank of Brazil.

URL: https : / /www.bcb.gov.br/content/publications / bankingreport/BAR_2017.pdf

Coelho, C., de Mello, J., Garcia, M. and Rigobon, R. (2017). A method for identifying aggregate credit supply and demand parameters using heteroskedascity: An application for Brazil, Working papers.

URL: http: / / www . economia.puc-rio.br/mgarcia/Hetero skedasticity_Credit_Demand_Supply_Mar_2017.pdf

CVM (2018). O mercado de dívida corporativa no Brasil: Uma análise dos desafios e propostas para seu desenvolvimento, Technical report, Comissão de Valores Mobiliários.

URL: http: //www.cvm.gov .br/noticias/arquivos/2019/ 20190411-1.html 
da Silva, G. J. C. and Pirtouscheg, L. A. S. (2015). Basic interest rate, bank competition and bank spread in personal credit operations in Brazil: A theoretical and empirical analysis, EconomiA 16(1): 32-45.

Dantas, J. A., de Medeiros, O. R. and Capelletto, L. R. (2012). Determinantes do spread bancário ex post no mercado Brasileiro, Revista de Administração Mackenzie 13(4): 48-74.

D'erasmo, P. N. (2016). Access to credit and the size of the formal sector, Economía 16(2): 143-199.

Fachada, P. (2008). Foreign banks' entry and departure: The recent Brazilian experience (1996-2006), Working Papers Series 164, Central Bank of Brazil, Research Department.

URL: https : / /www . bcb.gov.br/pec/wps/ingl/wps164 • p df

Gelos, R. G. (2009). Banking spreads in Latin America, Economic Inquiry 47(4): 796-814.

Hardy, B. (2019). Emerging markets' reliance on foreign bank credit, BIS Quarterly Review.

URL: https : / / www . bis.org/publ/qtrpdf/r_qt1903b.pdf

Hawtrey, K. and Liang, H. (2008). Bank interest margins in OECD countries, North American Journal of Economics and Finance 19(3): 249-260.

Itaú (2020). Gerenciamento de Riscos e Capital Pilar 3 1T20, Technical report, Itaú.

URL: https: / /www.itau.com.br/relacoes-com-investi dores /Download. aspx?Arquivo=c $9 r+F$ fMR $27 x$ tKWKpYRKOq $\mathrm{W}==$

Joaquim, G., Doornik, B. V. and Ornelas, J. R. (2019). Bank Competition, Cost of Credit and Economic Activity: evidence from Brazil, Working Papers Series 508, Central Bank of Brazil, Research Department.

URL: https : / /www.bcb.gov.br/pec/wps/ingl/wps508.p df

Jorgensen, O. H. and Apostolou, A. (2013). Brazil's bank spread in international context : From macro to micro drivers, Policy Research Working Paper Series 6611, World Bank.

URL: https : / openknowledge.worldbank .org/handle/1 $0986 / 16839$ 
Mishra, P., Montiel, P., Pedroni, P. and Spilimbergo, A. (2014). Monetary policy and bank lending rates in low-income countries: Heterogeneous panel estimates, Journal of Development Economics 111: 117-131.

Pazarbasioglu-Dutz, C., Byskov, S., Bonomo, M., Carneiro, I., Martins, B. and Perez, A. (2017). Brazil financial intermediation costs and credit allocation, World Bank.

Ramos-Tallada, J. (2015). Bank risks, monetary shocks and the credit channel in Brazil: Identification and evidence from panel data, Journal of International Money and Finance 55: 135-161.

Segura-Ubiergo, A. (2012). The Puzzle of Brazil's High Interest Rates, IMF Working Papers 2012/062, International Monetary Fund.

URL: https : / /www.imf .org/external/pubs/ft/wp/2012 /wp1262.pdf

Souza-Sobrinho, N. F. (2010). Macroeconomics of bank interest spreads: Evidence from Brazil, Annals of Finance 6(1).

Torres, E. and Zeidan, R. (2016). The life-cycle of national development banks: The experience of Brazil's BNDES, The Quarterly Review of Economics and Finance 62: 97-104.

Torres Filho, E., Macahyba, L. and Zeidan, R. (2014). Restructuring Brazil's National Financial System, IRIBA Working Paper 06, International Research Initiative on Brazil and Africa.

URL: https: //ideas.repec.org/p/bwp/bwppap/iriba_w p06.html

Valverde, S. C. and Fernández, F. R. (2007). The determinants of bank margins in European banking, Journal of Banking \& Finance 31(7).

World Bank (2019). Strength of legal rights index.

URL: https://data.worldbank.org/indicator/ic.lgl. cred.xq 